\title{
Recognition characters and new records of two species of Phylloscyrtini (Orthoptera, Gryllidae, Trigonidiinae) from southern Brazil
}

\author{
Luciano de P. Martins ${ }^{1}$, Darlan R. Redü ${ }^{2}$, Gabriel L. de Oliveira ${ }^{2} \&$ Edison Zefa $^{2}$ \\ 1. Instituto Nacional de Pesquisas da Amazônia (INPA), Coordenação de Pesquisas em Entomologia, Av. André Araújo, 2936, 69060-001, Manaus, Brazil. (lucianodpm@gmail.com) \\ 2. Universidade Federal de Pelotas (UFPel), Departamento de Zoologia e Genética, Campus Universitário Capão do Leão s/n, 96010-900, Capão do Leão, Brazil. (edzefa@gmail.com)
}

ABSTRACT. The Phylloscyrtini occurs from eastern United States to Argentina and includes 21 valid species. It is a highly neglected group of crickets and little is known about its biology and distribution. Cranistus colliurides Stål, 1861 and Phylloscyrtus amoenus (Burmeister, 1880) were recorded for the state of Rio Grande do Sul, southern Brazil, and information on calling song, stridulatory file and recognition characters were provided.

KEYWORDS. Cricket, calling song, genitalia, Grylloidea, Neotropical.

RESUMO. Reconhecimento de caracteres e novos registros de duas espécies de Phylloscyrtini (Orthoptera, Gryllidae, Trigonidiinae) do sul do Brasil. A tribo Phylloscyrtini ocorre do sul dos Estados Unidos a Argentina e inclui 21 espécies válidas. Trata-se de um grupo de grilos negligenciado e pouca informação a respeito de sua biologia e distribuição está disponível. Neste trabalho registramos Cranistus colliurides Stål, 1861 e Phylloscyrtus amoenus (Burmeister, 1880) no estado do Rio Grande do Sul e fornecemos informações a respeito de seu som de chamado, local de estridulação, veia estridulatória e outros caracteres importantes para o reconhecimento dos táxons.

PALAVRAS-CHAVE. Grilo, som de chamado, genitália, Grylloidea, Neotropical.

The tribe Phylloscyrtini was erected within the Trigonidiinae by CHOPARD (1968) for Phylloscyrtus Guérin-Méneville, 1844, Cranistus Stål, 1861, Phyllopalpus Uhler, 1864 and Myrmegryllus Fiebrig, 1907. Myrmegryllus was defined as incertae sedis in Trigonidiinae by Отте (1994).

The tribe occurs exclusively in the New World, members of it being present from eastern United States to Argentina (Desutter-Grandcolas, 1992), and comprises 21 species (EADEs et al., 2011). It is characterized by the foliaceus condition of the fifth joint of maxillary palpi, bright colored body, and features of the phallic sclerites (Desutter-Grandcolas, 1992).

It is a highly neglected group of crickets and available data are mostly about external morphology. Phyllopalpus pulchellus Uhler, 1864 is the only species to have data on its calling song published so far (WALKER, 1962).

In the present paper Cranistus colliurides Stål, 1861 and Phylloscyrtus amoenus (Burmeister, 1880) are recorded for the state of Rio Grande do Sul, southern Brazil, and information on calling song, stridulatory file, and recognition characters are provided.

\section{MATERIALS AND METHODS}

The specimens were collected in the cities of Capão do Leão and São Lourenço do Sul, state of Rio Grande do Sul, southern Brazil, from January to March 2008, 2009 and 2010.

The calling songs of the specimens were field and lab-recorded using a Nagra E recorder with Sennheiser $\mathrm{K} 6 / \mathrm{ME} 80$ microphone placed at $30 \mathrm{~cm}$ from the calling male. The temperature was measured at the male calling site.
The recorded songs were digitized at a sampling rate of $22.05 \mathrm{kHz}$ using the Avisoft SasLab Light software and a fast Fourrier transformation (FFT) was conducted. Sonograms were made using the following configuration: FFT-length of 256 points, $100 \%$ frame, FlatTop Window and window overlap of $75 \%$. Pulse rate was obtained calculating the number of pulse periods per second. The dominant frequency was obtained using the Cool Edit PRO software.

The tegmina were removed to analyze the number of teeth in the stridulatory file. Teeth number was counted with a light microscope at a magnification of $200 \mathrm{X}$ considering all teeth, including the smaller ones present on the edges of the file.

Body and right tegmen morphometry were measured in a stereomicroscope with graduated ocular.

The genitalia were removed and heated in $85 \%$ lactic acid according to Cumming (1992) and then placed in glass tubes with absolute alcohol for at least $96 \mathrm{~h}$ before manipulation. The specimens of $P$. amoenus were compared with the original descriptions and drawings. The specimens of $C$. colliurides were checked with the original descriptions and photographs of holotype, kindly made available to us by Gunvi Lindberg (Swedish Museum of Natural History, NHRS).

Four males and four females of each species were sent to the Museu de Zoologia da Universidade de São Paulo (MZUSP). The remaining specimens were deposited at the Departamento de Zoologia e Genética, Instituto de Biologia, Universidade Federal de Pelotas. Calling song sequences and image files were sent to Orthoptera Species File Online (http://Orthoptera. SpeciesFile.org). 


\section{RESULTS}

\section{Cranistus colliurides Stål, 1861}

(Figs 1-9, 20)

Cranistus colliurides STÅL, 1861: 316.

Type locality: Rio de Janeiro, Brazil, holotype ${ }^{\lambda}$ in Swedish Museum of Natural History (NHRS).

Recognition characters. Male: head and abdomen black, pronotum redish-brown (Fig. 1); red brown spot between the lateral ocelli (Fig. 3, arrow); tegmina reaching the apex of the abdomen; right tegmen black, lighter in the anterior region, harp and mirror with a hyaline portion; left tegmen with a hyaline central portion including mirror, harp, basal area and half of chordal area (Fig. 4); hind wings longer than tegmina (macropterous); stridulatory file with more than 100 teeth; hind femora light yellowish-green with a dark longitudinal streak on the outer side (Fig. 5).
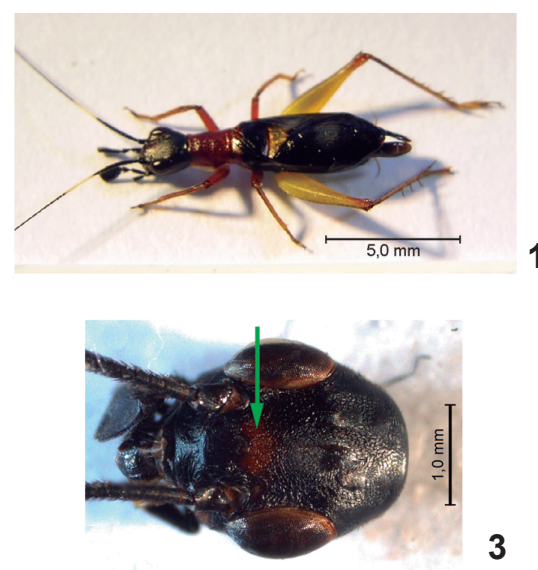

3

5
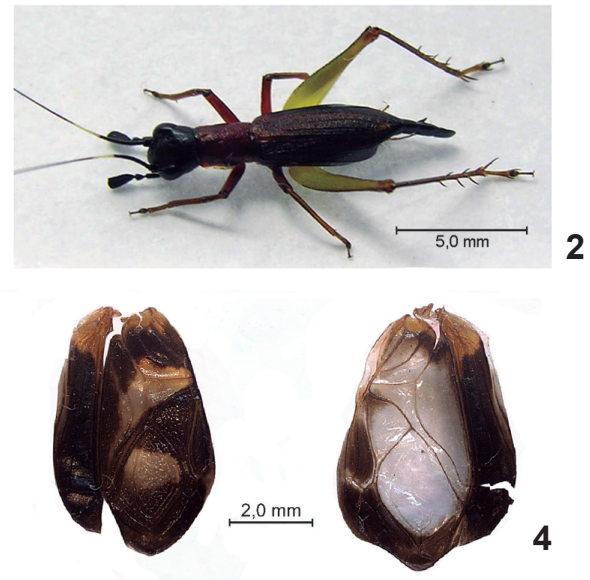

2 5.5; ovipositor length, 2.4-2.6. ranged from 6.5 to $7.3 \mathrm{kHz}$.

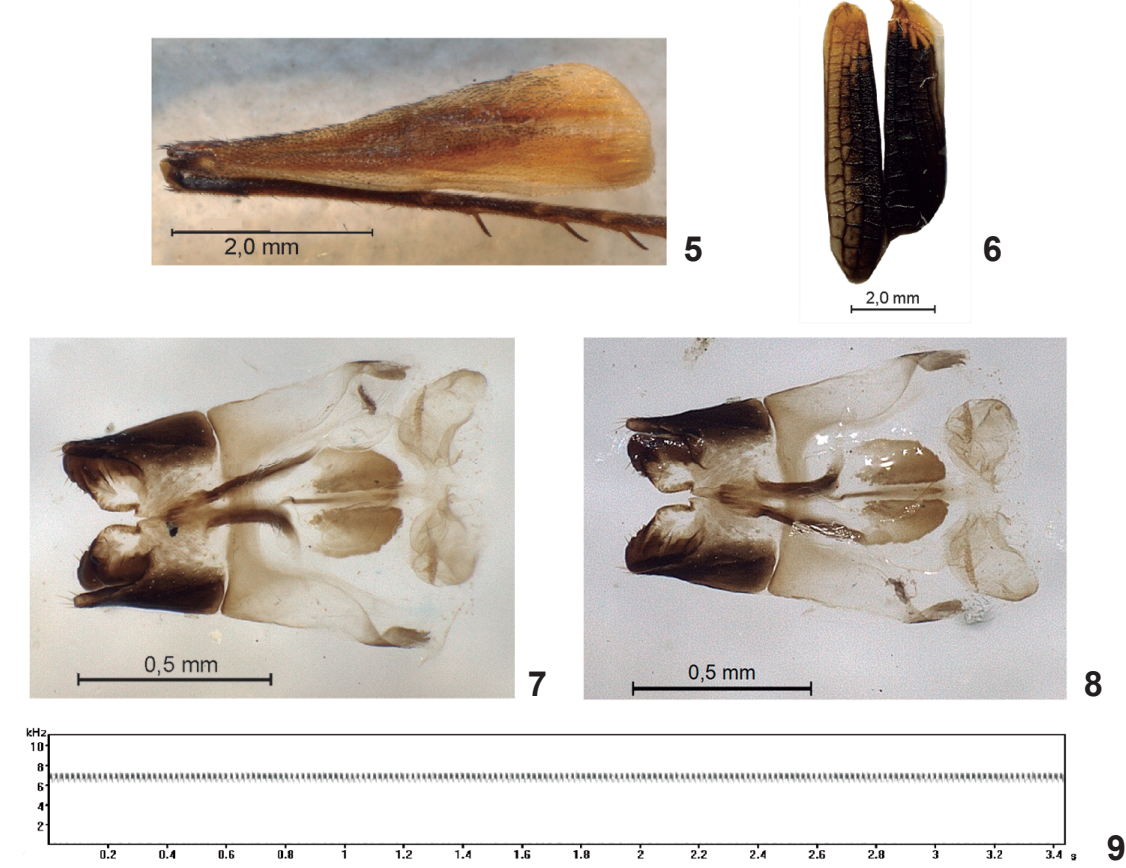
$5.6(\mathrm{n}=9)$; tegmen length, 5.7-6.6 $(\mathrm{n}=6)$; tegmen width, 3.6-4.2 (n=6); dorsal field width, 2.7-3.0 $(\mathrm{n}=6)$; lateral field width, $0.8-1.2(\mathrm{n}=6)$; teeth number (right tegmen), 109-122 ( $\mathrm{n}=11)$; left tegmen without stridulatory file. Female $(\mathrm{n}=4)$ : body length, 8.6-9.5; pronotum length, 2.1-2.3; pronotum width, 1.7-1.8; head width, 2.2-2.4; length of hind femur, 5.0-5.6; length of hind tibia, 5.1-

Calling song $(n=8)$. Continuous trill with pulse rate of $50-56 / \mathrm{s}$ at $29-31^{\circ} \mathrm{C}$. The dominant frequency without hyaline portions (Fig. 6). Calling song is a trill

Measurements (in mm). Male: body length, 8.9$9.2(\mathrm{n}=9)$; pronotum length, 1.9-2.1 $(\mathrm{n}=9)$; pronotum width, 1.6-1.9 $(\mathrm{n}=9)$; head width, 2.0-2.3 $(\mathrm{n}=9)$; length of hind femur, 4.8-5.5 $(\mathrm{n}=9)$; length of hind tibia, 4.6-

Figs 1-9. Cranistus colliurides Stål, 1861: 1, male, dorsal view; 2, female, dorsal view; 3, dorsal view of the head, red brown spot (arrow); 4, ventral view of the male tegmina, right and left; 5, outer side of femur III; 6, dorsal view of the female right tegmen; male genitalia: 7, dorsal view; 8, ventral view; 9, calling song sonogram, trill at $30^{\circ} \mathrm{C}$. 
Material examined. BRAZIL, Rio Grande do Sul: Capão do Leão (Universidade Federal de Pelotas, $31^{\circ} 48^{\prime} 00^{\prime \prime} \mathrm{S}, 52^{\circ} 25^{\prime} 06^{\prime} \mathrm{W}$ ), 50', 29, 11-18.III.2008, E. Zefa col.; (Horto Botânico Ir. Teodoro

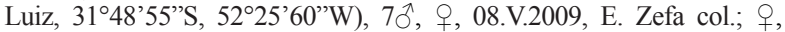
11.III.2010, D. Redü col.; São Lourenço do Sul (São João da Reserva, $6^{\circ}$

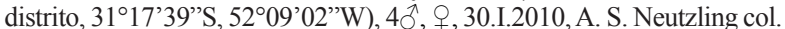

Geographical records (Fig. 20). Argentina (SAUSSURE, 1874); Brazil, state of Rio de Janeiro: Rio de Janeiro (STÅL, 1861), Petrópolis (ReHn, 1917; Costa-Lima, 1958) and Nova Friburgo (SAUSSURE, 1878); state of Rio Grande do Sul: Capão do Leão and São Lourenço do Sul (new records).

\section{Phylloscyrtus amoenus Burmeister, 1880 \\ (Figs 10-20)}

Phylloscirtus amoenus BurmeIster, 1880:17-18. found.

Type locality: Buenos Aires, Argentina. Type not

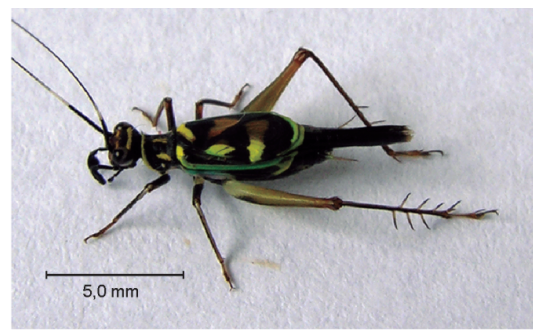

Recognition characters. Male: head pale brown with a black interocular stripe and a black spot along the vertex, occiput and postgenae (Figs 10, 12, 13); pronotum black with a pale stripe along the anterior and lateral margins (Figs 12, 13) and three pale longitudinal bands, one median and two laterals (Fig. 12); tegmina not reaching the apex of the abdomen; dorsal field of the right tegmen black with four yellow spots, one in basal area, two in chordal and another in apical area, and three pale spots becoming hyaline, one in harp and mirror and another beside the yellow one in chordal area; dorsal field of the left tegmen largely hyaline with some black portions on the edge and a yellow spot in the apical area; lateral field with hyaline, yellow and black portions in both tegmina (Fig. 14); macropterous and micropterous specimens present, in the former ones the wings are twice the length of tegmina; stridulatory

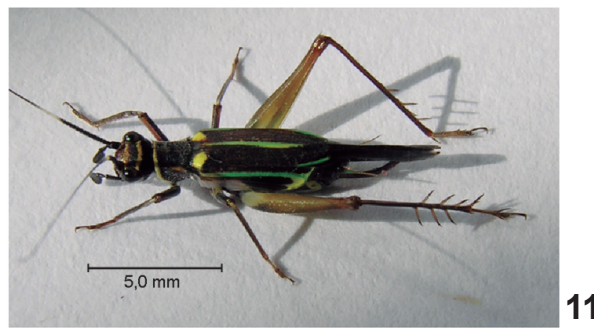

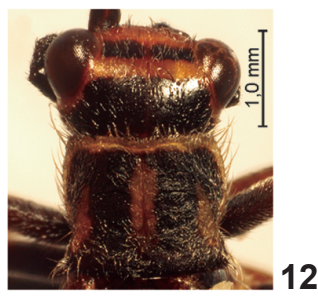
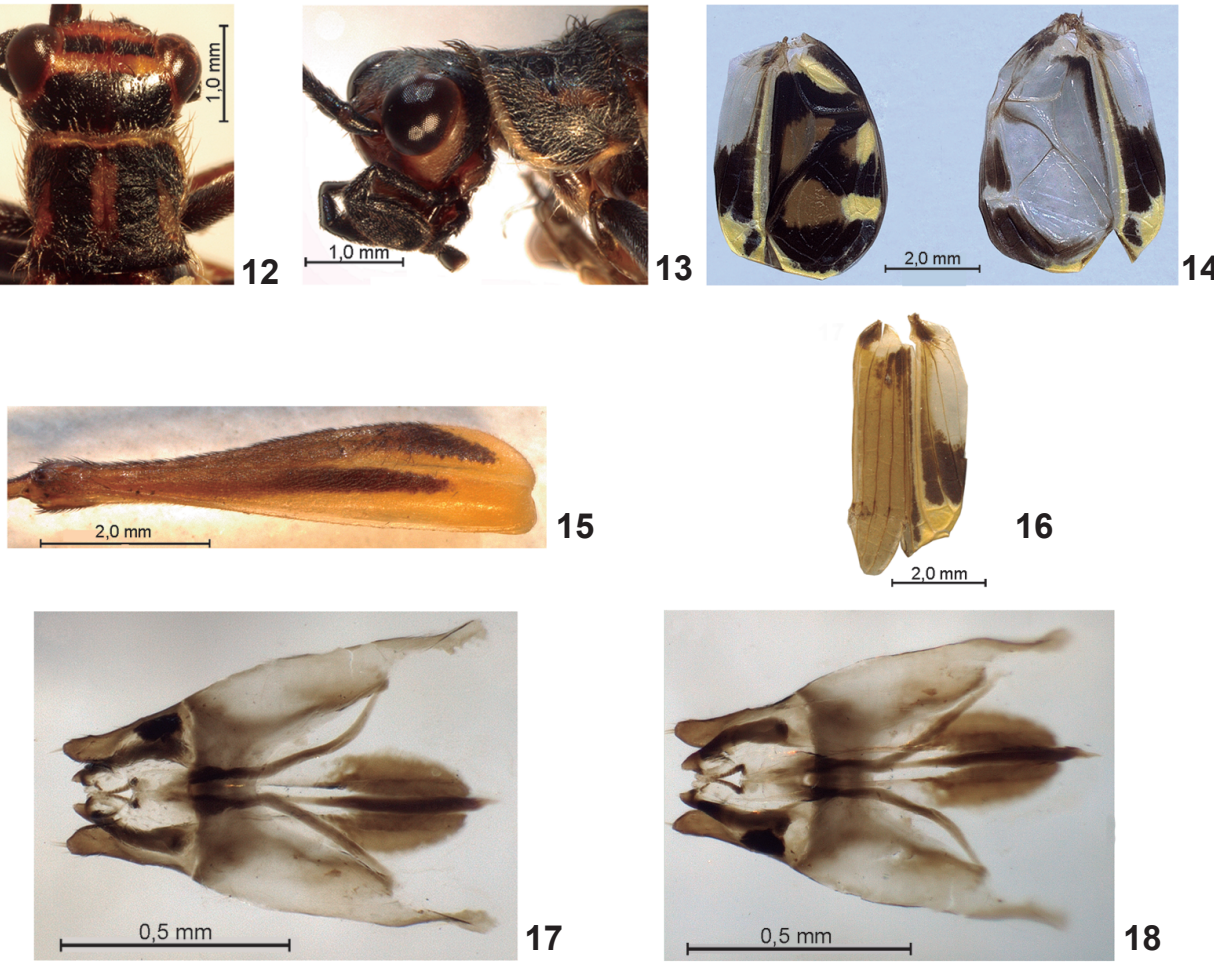

17
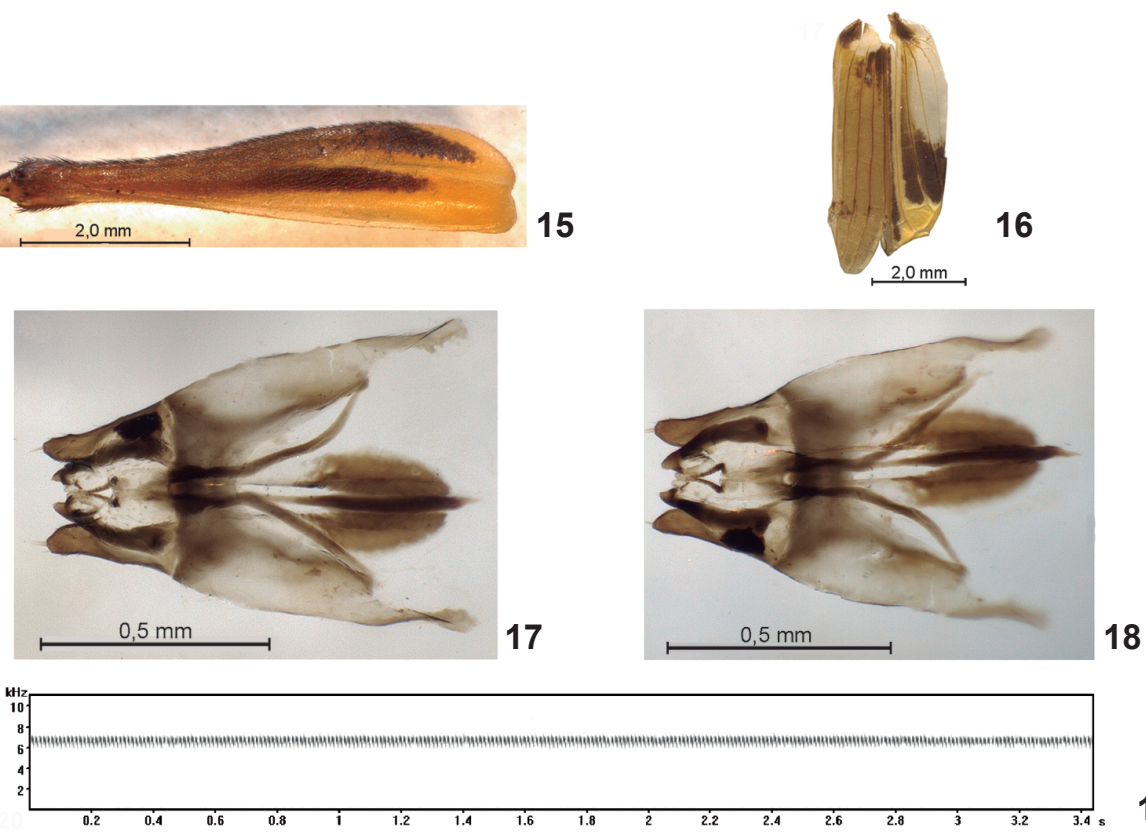

Figs 10-19. Phylloscirtus amoenus Burmeister, 1880. 10, male, dorsal view; 11, female, dorsal view; head and pronotum: 12, dorsal view; 13, lateral view; 14, ventral view of the male tegmina, left and right; 15, outer side of femur III; 16, dorsal view of the female right tegmen; male genitalia: 17, dorsal view; 18 , ventral view; 19 , calling song sonogram, trill at $29^{\circ} \mathrm{C}$. 
file with less than 90 teeth; hind femora with a dark longitudinal streak bifurcated proximally, on the outer face (Fig. 15). Female: similar to male (Fig. 11) but the dorsal field of its tegmina pale brown without hyaline portions (Fig. 16). Calling song is a trill with pulse rate of $77-83 / \mathrm{s}$ at $29-31^{\circ} \mathrm{C}$ (Fig. 19).

Measurements (in mm). Male: body length, 7.8$8.8(\mathrm{n}=10)$; pronotum length, $1.4-1.6(\mathrm{n}=10)$; pronotum width, 1.7-1.9 ( $\mathrm{n}=10)$; head width, 2.0-2.1 $(\mathrm{n}=10)$; length of hind femur, 5.6-6.0 $(\mathrm{n}=10)$; length of hind tibia, 5.5-6.4 $(\mathrm{n}=10)$; tegmen length, 4.8-5.5 $(\mathrm{n}=7)$; tegmen width, 3.5-3.9 $(\mathrm{n}=7)$; dorsal field width, 2.5-2.8 $(\mathrm{n}=7)$; lateral field width, 1.0-1.1 $(\mathrm{n}=7)$; teeth number (right tegmen), 78-88 $(\mathrm{n}=13)$; left tegmen without stridulatory file. Female $(\mathrm{n}=4)$ : body length, 8.4-8.8; pronotum length, 1.7-1.8; pronotum width, 1.8-2.2; head width, 2.2-2.3; length of hind femur, 6.2-6.5; length of hind tibia, 6.2-6.5; ovipositor length, 2.9-3.1.

Calling song $(\mathrm{n}=10)$. Continuous trill with pulse rate of $77-83 / \mathrm{s}$ at $29-31^{\circ} \mathrm{C}$. The dominant frequency ranged from 6.2 to $7.5 \mathrm{kHz}$.

Material examined. BRAZIL, Rio Grande do Sul: Capão do Leão (Universidade Federal de Pelotas, $\left.31^{\circ} 48^{\prime} 00^{\prime \prime} \mathrm{S}, 52^{\circ} 25^{\prime} 06^{\prime} \mathrm{W}\right), 6{ }^{\prime}$, 2 , 18.III.2008, E. Zefa col.; Capão do Leão (Horto Botânico Ir. Teodoro

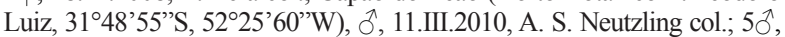
11-17.III.2010, D. Redü col.; São Lourenço do Sul (São João da Reserva, $6^{\circ}$

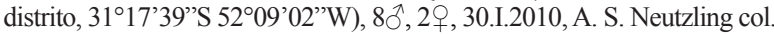

Geographical records (Fig. 20). Argentina: province of Buenos Aires, Buenos Aires (Burmeister, 1880; Rehn, 1913); province of Formosa, Lapango (Hebard, 1931). Paraguay: department of San Pedro (Giglio-Tos, 1894; 1895); Costa Rica: La Selva (Otтe, 2006). Brazil: state of Rio Grande do Sul: Capão do Leão and São Lourenço do Sul (new records).

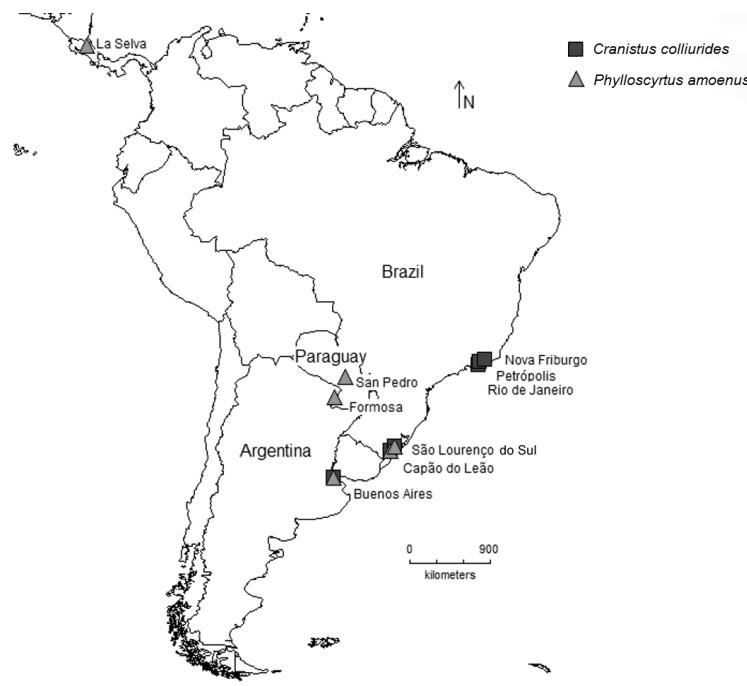

Fig. 20. Geographical records of Cranistus colliurides Stål, 1861 and Phylloscirtus amoenus Burmeister, 1880.
Comments. Populations of $C$. colliurides and $P$. amoenus occur in sympatry and high densities, stridulating at both, night and day periods, sharing the same places on the vegetation, such as branches, twigs and leaves of shrubs and grasses.

Acknowledgments. We wish to thank Alexandre Schneid Neutzling and Fernando Albuquerque Luz for helping to collect specimens, and Elisa Milach for helping in the genitalia cleaning technique. Research supported by CAPES (Coordenação de Aperfeiçoamento de Pessoal de Nível Superior) and CNPq (Conselho Nacional de Desenvolvimento Científico e Tecnológico, 302727/20078, CNPq/Universal 473045/2007-9, CNPq/PROSET 556871/2009-0 and CNPq/SISBIOTA 563360/2010-0).

\section{REFERENCES}

BurmeISTER, H. 1880. Cephalocoema und Phylloscyrtus, zwei merkwürdige Orthopteren-Gattungen der Fauna Argentina. Abhandlungen der Naturforschenden Gesellschaft zu Halle 15:1-20.

Chopard, L. 1968. Pars 12 Gryllides. Fam. Gryllidae: Subfam. Mogoplistinae, Myrmecophilinae, Scleropterinae, Cachoplistinae, Pteroplistinae, Pentacentrinae, Phalangopsinae, Trigonidiinae, Eneopterinae; Fam. Oecanthidae, Gryllotalpidae. In: Beier, M. ed. Orthopterorum Catalogus. 's-Gravenhage, Uitgeverij Dr. W. Junk N. V. p.215-500.

Costa-Lima, A. 1958. Sôbre três grilos americanos (Orth. Grylloidea: Eneopteridae e Trigonidiidae). Anais da Academia Brasileira de Ciências 30:111-118.

Cumming, J. M. 1992. Lactic acid as an agent for macerating Diptera specimens. Fly Times 8:7.

DesutTer-GrandColas, L. 1992. Etude phylogénétique, biogéographique et écologique des Grylloidea Néotropicaux (Insectes, Orthoptères). Bulletin de la Société Zoologique de France 117:82-86.

Eades, D. C.; Otte, D.; Cigliano, M. M. \& Braun, H. 2011. Orthoptera Species File Online. Version 2.0/4.0. Available at: $<\mathrm{http} / / /$ orthoptera.speciesfile.org/>. Accessed on 24 January 2011.

Giglio-Tos, E. 1894. Viaggio dell dott. Alfredo Borelli nella Republica Argentina e nel Paraguay. VI, Ortotteri. Bollettino dei Musei di Zoologia ed Anatomia Comparata della Reale Università di Torino 9:1-46.

. Ortotteri del Paraguay, racolti dal Dr. J. Bohls. Zoologischen Jahrbüchern 8:804-818.

Hebard, M. 1931. Die Ausbeute der deutschen Chaco-Expedition 1925/26. Orthoptera. Konowia 10:257-285.

Отте, D. 1994. Orthoptera Species File. Number 1: Crickets (Grylloidea). Philadelphia, The Orthopterists' Society \& The Academy of Natural Sciences of Philadelphia. 120p.

2006. Eighty-four new cricket species (Orthoptera: Grylloidea) from La Selva, Costa Rica. Transactions of the Americam Entomological Society 132:299-418.

ReHN, J. A. G. 1913. A contribution to the knowledge of the Orthoptera of Argentina. Proceedings of the Academy of Natural Sciences of Philadelphia 63:273-379.

1917. On Orthoptera from the vicinity of Rio de Janeiro, Brazil. Transactions of the Americam Entomological Society 43:335-364.

Saussure, H. 1874. Mission Scientifique au Mexique et dans l'Amérique Centrale, 6e Partie: Études sur les Myriapodes et les Insectes. Paris, Imprimerie Impériale. $531 \mathrm{p}$.

. 1878. Mèlanges orthoptèrologiques. VIème fascicule. Gryllides (2ème partie). Mémoires de la Societé de Physique et d'Histoire Naturelle de Genève 25:369-702.

STÅL, C. 1861. Orthoptera. Kongliga Svenska Fregatten Eugenies Resa Omkring Jorden under Befäl af C. A. Virgin Åren 1851-1853. Uppsala, Stockholm, Almquist \& Wiksells. vol. 2, Zoologi, Insecta.

WALKER, T. J. 1962. Factors responsible for intraespecific variation in the calling song of crickets. Evolution 16:407-428.

Recebido em 19 de setembro de 2011. Aceito em 17 de fevereiro de 2012. ISSN 0073-4721

Artigo disponível em: www.scielo.br/isz 